\title{
Biofortification efficiency with magnesium salts on the increase of bioactive compounds and antioxidant capacity in snap beans
}

\section{Juan Pablo Ciscomani-Larios ${ }^{1}$ (D) Esteban Sánchez-Chávez ${ }^{2}$ (i) Juan Luis Jacobo-Cuellar ${ }^{1}$ (D) Hilda Karina Sáenz-Hidalgo ${ }^{2}$ (i) Nuvia Orduño-Cruz ${ }^{1}$ (c) Oscar Cruz-Alvarez ${ }^{1}$ (D) Graciela Dolores Ávila-Quezada ${ }^{* *}$ (I)}

${ }^{1}$ Universidad Autónoma de Chihuahua (UACH), Facultad de Ciencias Agrotecnológicas, 31000, Chihuahua, México. E-mail: gavilaq@gmail.com. ${ }^{*}$ Corresponding author.

${ }^{2}$ Centro de Investigación en Alimentación y Desarrollo A.C. Delicias, Chihuahua, México.

ABSTRACT: Biofortification of food crops is implemented through the application of mineral fertilizers, to improve the levels of essential mineral elements for human nutrition. Magnesium is a key macronutrient in crop production and quality; however, worldwide, it is the most limiting macronutrient in agriculture. Magnesium plays an important role in manipulating physiological and biochemical processes in plants. Therefore, the objective of this study was to evaluate the efficacy of biofortification with magnesium chloride and sulfate on the accumulation of bioactive compounds and antioxidant capacity in snap bean cv. Strike. Two sources of Magnesium were applied via edaphic route: Magnesium chloride and magnesium sulfate at doses of 0, 50, 100 and 200 ppm during 2018 in Mexico. Accumulation of bioactive compounds (total phenols, total flavonoids and total anthocyanins) and antioxidant capacity in snap bean fruits were evaluated. Results obtained indicate that the concentration of total flavonoids, total anthocyanins and antioxidant capacity in the edible parts of snap beans were higher in the $\mathrm{MgSO}_{4}$ treatment than in the $\mathrm{MgCl}_{2}$ treatments, exceeding 30, 59 and $6 \%$ respectively. This is one of the first studies on the edaphic agronomic biofortification of $\mathrm{Mg}^{+}$and its effect on nutraceutical quality in snap bean. An interesting result is that $\mathrm{MgSO}_{4}$ produced high concentrations of anthocyanins in edible snap beans. These results can be applied as a new strategy to reduce malnutrition and improve the health of the population in poor urban and rural communities in developing countries.

Key words: anthocyanins, antioxidant capacity, edaphic biofortification, flavonoids.

Eficiência da biofortificação com sais de magnésio no aumento de compostos bioativos e capacidade antioxidante em feijão-vagem

RESUMO: A biofortificação de culturas alimentares é implementada através da aplicação de fertilizantes minerais, para melhorar os níveis de elementos minerais essenciais para a nutrição humana. O magnésio é um macronutriente essencial na produção e qualidade das culturas, no entanto, em todo o mundo, é o macronutriente mais limitante da agricultura. O magnésio desempenha um papel importante na manipulação de processos fisiológicos e bioquímicos nas plantas. Portanto, o objetivo deste estudo foi avaliar a eficácia da biofortificação com cloreto e sulfato de magnésio no acúmulo de compostos bioativos e capacidade antioxidante em feijões verdes cv. Strike. Duas fontes de magnésio foram aplicadas por via edáfica: cloreto de magnésio e sulfato de magnésio nas doses de 0, 50, 100 e 200 ppm durante o ano de 2018 no México. Foram avaliados o acúmulo de compostos bioativos (fenóis totais, flavonóides totais e antocianinas totais) e a capacidade antioxidante em frutos de feijão-vagem. Os resultados obtidos indicam que a concentração de flavonoides totais, antocianinas totais e capacidade antioxidante nas partes comestíveis do feijão-vagem foram maiores no tratamento com $\mathrm{MgSO}_{4}$ do que nos tratamentos com $\mathrm{MgCl}_{2}$, ultrapassando 30 , 59 e $6 \%$ respectivamente. Este é um dos primeiros estudos sobre a biofortificação agronômica edáfica do $\mathrm{Mg}+$ e seu efeito na qualidade nutracêutica do feijão-vagem. Um resultado interessante é que o $\mathrm{MgSO}$ produziu altas concentrações de antocianinas no feijão-vagem comestivel. Esses resultados podem ser aplicados como uma nova estratégia para reduzir a desnutrição e melhorar a saúde da população em comunidades urbanas e rurais pobres em países em desenvolvimento.

Palavras-chave: antocianinas, capacidade antioxidante, biofortificação edáfica, flavonóides.

\section{INTRODUCTION}

The common bean is the world's most widely cultivated and important food legume, grown for direct human consumption (FAO, 2018).
In the soil, the bean crop fixes nitrogen from the air (RONDON et al., 2007); nevertheless, the diet of the world population that consume grains and cereals or regions where mineral imbalances of the soil live, often lack magnesium $(\mathrm{Mg}+)$ among others (WHITE 
\& BROADLEY, 2009). Mg+ is an important element in human nutrition, being the next most abundant intracellular cation after potassium (ALHOSAINI \& LEEHEY, 2015), and involved in more than 600 different enzymatic reactions.

Some of the main functions of magnesium in the human body are the maintenance of ionic gradients, cellular and tissue integrity, mitochondrial oxidative phosphorylation and the synthesis of nucleic acids and proteins (WACKER \& PARISI, 1968; ABBOTT \& RUDE, 1993). Human nutritional deficiency in $\mathrm{Mg}+$ is associated with a number of diseases (DE BAAIJ et al., 2015). Due to medications, reduced magnesium content in food crops, and the availability of refined and processed foods, people are at risk for magnesium deficiency. People will need to supplement with magnesium to prevent element deficiency, and have an optimal level of magnesium to prevent chronic disease (ROSANOFF, 2013).

Mineral malnutrition can be reduced by enriching the food and/or by increasing the bioavailability of the mineral elements in the edible organs of food crops. In plants, $\mathrm{Mg}+$ is important because it is the central atom in chlorophyll and is involved in a range of physiological processes (HÖRTENSTEINER \& KRÄUTLER, 2011). Nonetheless, few investigations have been carried out on $\mathrm{Mg}+$ when added to the soil to achieve edaphic biofortification of major food crops.

According to BOUIS \& SALTZMAN (2017), biofortification programs for food crops with essential nutrients can mitigate or eliminate problems related to micronutrient malnutrition. However, because mineral supplementation of food products is not always effective, food crop biofortification is proposed through the application of mineral fertilizers combined with the use of improved plant varieties having greater capacity to acquire mineral elements from mineral deficient soils (BOUIS \& WELCH, 2010).

Our research group are currently engaged in studies focusing on biofortification as a management strategy for enhancing nutrient accumulation in the edible organs of various food crops. This study evaluated the effects of magnesium sulphate $\left(\mathrm{MgSO}_{4}\right)$ and magnesium chloride $\left(\mathrm{MgCl}_{2}\right)$ on total phenols, anthocyanins, flavonoids and antioxidant capacity.

\section{MATERIALS AND METHODS}

\section{Plant material and location of the experiment}

A plot experiment was conducted in the open field from August 30 to November 7 at an experimental location in the Facultad de Ciencias Agrotecnologicas at the Universidad Autonoma de Chihuahua in Chihuahua, Mexico (28 39' $19^{\prime \prime} \mathrm{N}$ and $106^{\circ} 05^{\prime} 14^{\prime \prime} \mathrm{W}$ ) in 2018. Four seeds of 'common bean' Phaseolus vulgaris L. 'Strike' were placed $3 \mathrm{~cm}$ deep in pots (4 L) filled with a vermiculite : perlite mixture 2:1 (v:v). Under the prevailing conditions (mean diurnal temperature $28{ }^{\circ} \mathrm{C}$ ) the seeds germinated after six days. A total of 160 plants were established in 40 pots.

\section{Magnesium biofortification}

Six days after germination, the plants received the nutrient solution proposed by STEINER (1961) as adjusted by MÁRQUEZ-QUIROZ et al. (2015) consisting of $6 \mathrm{mM}$ of $\mathrm{NH}_{4} \mathrm{NO}_{3}, 1.6 \mathrm{mM}$ of $\mathrm{K}_{2} \mathrm{HPO}_{4}, 0.3 \mathrm{mM}$ of $\mathrm{K}_{2} \mathrm{SO}_{4}, 4.0 \mathrm{mM}$ of $\mathrm{CaCl}_{2} \cdot 2 \mathrm{H}_{2} \mathrm{O} 1.4$ $\mathrm{mM}$ of $\mathrm{MgSO}_{4} \cdot 7 \mathrm{H}_{2} \mathrm{O}, 2 \mu \mathrm{M}$ of $\mathrm{MnSO}_{4} \cdot \mathrm{H}_{2} \mathrm{O}, 1.0 \mu \mathrm{M}$ of $\mathrm{ZnSO}_{4} \cdot 7 \mathrm{H}_{2} \mathrm{O}, 0.25 \mu \mathrm{M}$ of $\mathrm{CuSO}_{4} \cdot 5 \mathrm{H}_{2} \mathrm{O}, 0.3 \mu \mathrm{M}$ of $\left(\mathrm{NH}_{4}\right) 6 \mathrm{Mo}_{7} \mathrm{O}_{24} \cdot 4 \mathrm{H}_{2} \mathrm{O}$, and $0.5 \mu \mathrm{M}$ of $\mathrm{H}_{3} \mathrm{BO}_{3}$. The bean plants were watered every three days with the nutrient solution to compensate for water loss by evaporation. The $\mathrm{Mg}$ treatments were applied starting 26 days after germination and over a period of 40 days.

Two $\mathrm{Mg}$ treatments were established using either $\mathrm{MgCl}_{2}$ or $\mathrm{MgSO}_{4}$. Based on previous reports (MÁRQUEZ-QUIROZ et al., 2015; SIDAARREOLA et al., 2015) four levels of treatment of $0,50,100$ and $200 \mathrm{ppm}$, with four replicates per treatment were established. A completely randomized experimental design was used. The experimental unit was a pot with four plants. Plant material was sampled 60 days after completion of the growth cycle. The fresh snap beans were stored at $-20{ }^{\circ} \mathrm{C}$. Frozen snap beans were ground at $4{ }^{\circ} \mathrm{C}$ for $5 \mathrm{~min}$ by mechanical maceration in a mortar with pestle.

\section{Bioactive compounds (BC) \\ Extraction and quantification of total phenols}

The extraction of total phenols from the snap beans was determined as recommended by SINGLETON \& ROSSI (1965) and SINGLETON et al. (1985) with slight modifications. One gram of ground snap bean was standardized with $80 \%$ methanol 10 $\mathrm{mL}$ for $5 \mathrm{~min}$. Then, it was filtered through qualitative filter paper and centrifuged at $6000 \mathrm{rpm}$ for $10 \mathrm{~min}$ at $4{ }^{\circ} \mathrm{C}$ to obtain a methanolic phase.

To quantify the total phenols, the reaction mixture contained $750 \mu \mathrm{L}$ of $2 \% \mathrm{Na}_{2} \mathrm{CO}_{3}$ (J.T. Baker, Mexico state, Mexico), $250 \mu \mathrm{L}$ of $50 \%$ FolinCiocalteau reagent (Sigma-Aldrich, St. Louis, MO, USA), $1375 \mu \mathrm{L}$ of deionized $\mathrm{H}_{2} \mathrm{O}$. The mixture was incubated in darkness for $60 \mathrm{~min}$, and then the 
absorbance was registered at $725 \mathrm{~nm}$. Results were expressed in $\mathrm{mg}$ of gallic acid equivalents $\mathrm{g}^{-1}$ ( $\mathrm{mg}$ $\mathrm{GAE}^{-1}$ ) of fresh weight (fw).

\section{Total flavonoids}

The colorimetric method proposed by ZHISHEN et al. (1999) was used. Amounts of $1 \mathrm{~g}$ of ground snap bean was standardized with $10 \mathrm{~mL}$ of $80 \%$ methanol for $5 \mathrm{~min}$. Then, it was filtered through filter paper and centrifuged at $6000 \mathrm{rpm}$ at $4{ }^{\circ} \mathrm{C}$ for $10 \mathrm{~min}$. The mixture consisted in $250 \mu \mathrm{L}$ of the aliquot, plus $75 \mu \mathrm{L}$ of $\mathrm{NaNO}_{2}$ (J.T. Baker, Mexico state, Mexico), mixed in a vortex stirrer and allowed to rest for $5 \mathrm{~min}$. Then, $150 \mu \mathrm{L}$ of $\mathrm{AlCl}_{3}$ (J.T. Baker, Mexico state, Mexico) were added, followed by 500 $\mu \mathrm{L}$ of $\mathrm{NaOH}$ (J.T. Baker, Mexico State, Mexico). Water was added to reach a final volume of $2.025 \mathrm{~mL}$ The mixture was incubated in darkness for $45 \mathrm{~min}$. The absorbance was registered at $510 \mathrm{~nm}$. Catechin was used as the standard compound, and the total flavonoid content was expressed as $\mathrm{mg}$ of catechin equivalents $(\mathrm{CE}) \mathrm{g}^{-1}$ of fw of the sample.

\section{Total anthocyanins}

Amounts of $1 \mathrm{~g}$ of the ground snap bean was standardized in $10 \mathrm{~mL}$ of $80 \%$ methanol for $5 \mathrm{~min}$. Then, it was filtered through filter paper and the mixture was centrifuged at $6000 \mathrm{rpm}$ at $4{ }^{\circ} \mathrm{C}$ for $10 \mathrm{~min}$.

After centrifugation, two phases were obtained. From the first phase, $0.5 \mathrm{~mL}$ was taken and $2 \mathrm{~mL}$ of potassium chloride was added. This was vortexed and absorbance (A) was measured by spectrophotometry (A460) using a JENWAY Spectrophotometer, Jenway Limited $^{\circledR}$, Essex, England. From the second phase, $0.5 \mathrm{~mL}$ was taken and $2 \mathrm{~mL}$ of sodium acetate was added. This was vortexed and the absorbance was registered at $710 \mathrm{~nm}$. Results were reported in mg of cyanidin-3-glucoside $\mathrm{g}^{-1}$. The analyses of $\mathrm{BC}$ were carried out in triplicate.

\section{Antioxidant capacity}

The antioxidant capacity of snap beans was determined using the 2, 2-diphenyl-1-picrylhydrazyl (DPPH) method according to the methodology proposed by HSU et al. (2003). The methanolic extract was prepared by soaking $1 \mathrm{~g}$ of ground snap beans in $10 \mathrm{~mL}$ of $80 \%$ methanol for $5 \mathrm{~min}$. Then, it was filtered through filter paper and the resulting mixture was centrifuged at $6000 \mathrm{rpm}$ for $10 \mathrm{~min}$ at $4{ }^{\circ} \mathrm{C}$. Then $0.5 \mathrm{~mL}$ of the supernatant was mixed with $2.5 \mathrm{~mL}$ of freshly prepared $0.1 \mathrm{mM}$ DPPH solution. The mixture was kept in the dark for $60 \mathrm{~min}$ at low temperature $\left(5^{\circ} \mathrm{C}\right)$. Absorbance was recorded at $517 \mathrm{~nm}$. For the blank solution, the extract was replaced with $0.5 \mathrm{~mL}$ of methanol. The DPPH radical-scavenging activity was calculated as:

Percentage of scavenging activity $=\left[1-\left(\frac{A 517 \text { sample }}{A 517 \text { blank }}\right)\right] \times 100$

\section{Statistical analyses}

Results were analyzed by analysis of variance and a comparison of means with LSD media separation test in SAS program (SAS Inst. Inc., Cary, NC, USA). Means were deemed significantly different at $p \leq 0.05$.

\section{RESULTS AND DISCUSSION}

\section{Bioactive compounds Total phenols}

'Common beans' are rich in bioactive compounds (BC). Phenolics are among those BC having metabolic roles in the human body (SUÁREZMARTÍNEZ et al., 2016). The average of total phenols across the various $\mathrm{Mg}$ doses $(0,50,100$ and $200 \mathrm{ppm})$ varied from $0.33 \mathrm{mg} \mathrm{GAE} \mathrm{g}^{-1}\left(\mathrm{MgSO}_{4}\right)$ to $0.344 \mathrm{mg}$ GAE $\mathrm{g}^{-1}\left(\mathrm{MgCl}_{2}\right)$ with no significant difference $(p \leq$ 0.05 ) between the two $\mathrm{Mg}$ salts (Figure 1A). The $100 \mathrm{ppm}$ dose of $\mathrm{MgSO}_{4}$ and $\mathrm{MgCl}_{2}$ showed the highest phenols concentrations and was the only dose that exceeded the control, with which there was a statistically significant difference $(p \leq 0.05)$ (Figure $2 \mathrm{~A}$ ). This dose of $\mathrm{MgCl}_{2}$ yielded $0.49 \mathrm{mg} \mathrm{GAE} \mathrm{g}^{-1}$ in snap beans and of $\mathrm{MgSO}_{4}$ yielded $0.46 \mathrm{mg} \mathrm{GAE} \mathrm{g}^{-1}$ of snap beans, while the controls were 0.38 and $0.39 \mathrm{mg} \mathrm{GAE}$ $\mathrm{g}^{-1}$, respectively

Low concentrations of phenols are common in snap beans (HANAFY-AHMED et al., 2010) plants amended with humic acid and foliar applications of macro-elements. They reported total soluble phenols concentrations in snap beans of 0.13 to $0.24 \mathrm{mg} \mathrm{GAE} \mathrm{g}^{-1}$ of fw and in control snap beans of 0.1 to $0.12 \mathrm{mg} \mathrm{GAE} \mathrm{g}^{-1}$ of fw. Their values are smaller than the range reported in our study.

\section{Total flavonoids}

The average concentrations of total flavonoids was $0.19 \mathrm{mg} \mathrm{CE} \mathrm{g}^{-1}$ for $\mathrm{MgCl}_{2}$ and 0.26 $\mathrm{mg} \mathrm{CE} \mathrm{g}^{-1}$ for $\mathrm{MgSO}_{4}$. These values are statistically different ( $p \leq 0.05)$ (Figure 2B).

The $200 \mathrm{ppm} \mathrm{MgCl}_{2}$ or $\mathrm{MgSO}_{4}$ doses yielded the highest flavonoids concentrations, with the differences being significantly $(p \leq 0.05)$ higher than the controls and other treatments. HEIMLER et al. (2005) also reported low flavonoids content in dried common bean seeds from 12 samples from Italy. Their values ranged from 0.22 - $1.4 \mathrm{mg} \mathrm{CE} \mathrm{g}^{-1}$ seeds dw. 


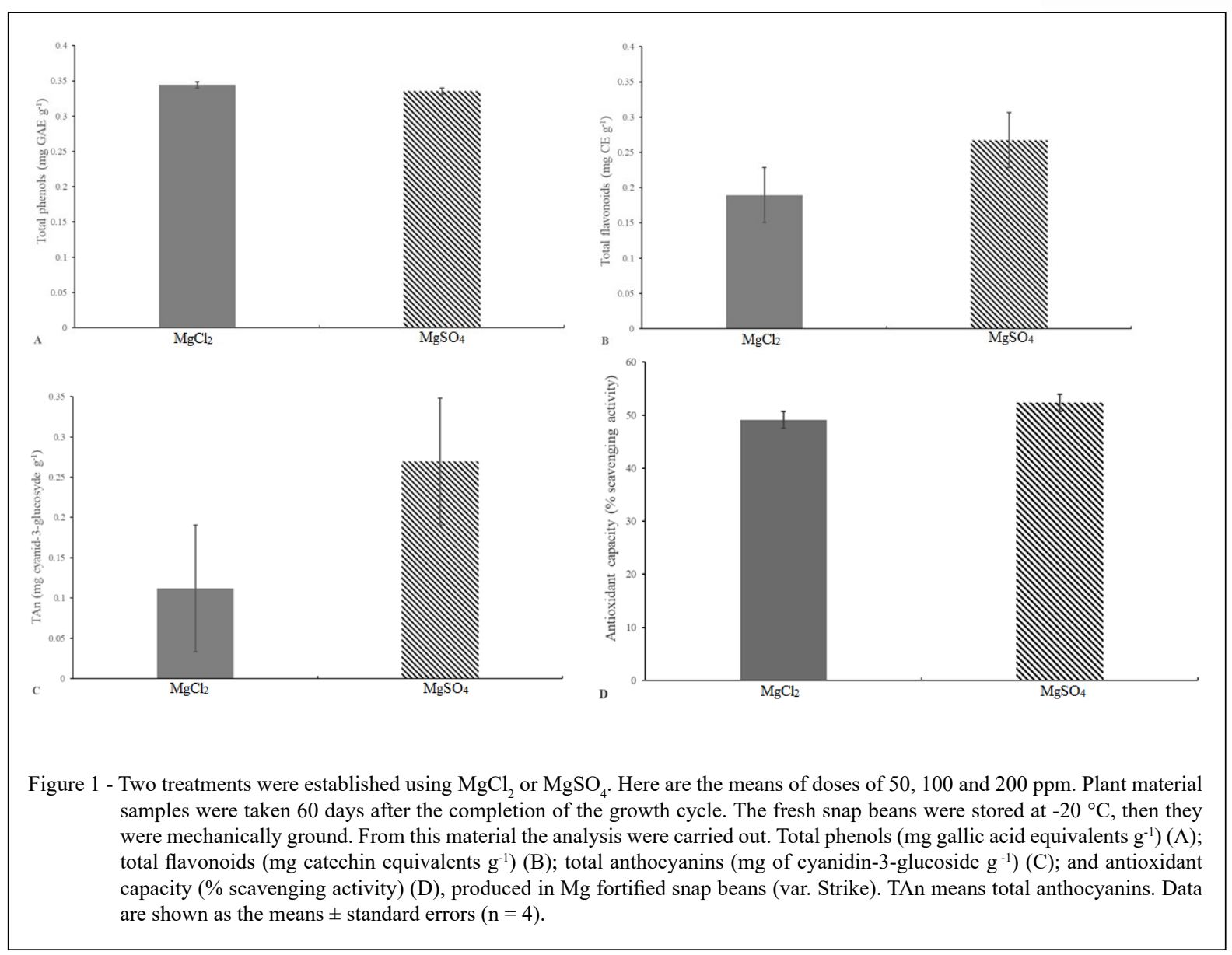

The consumption of flavonoids has been reported to be inversely correlated with incidence of some types of cancer and cardiovascular disease (DAVID et al., 2016). Their putative mechanism involves detoxification of enzymes and inhibition of cell proliferation (DÍAZ-BATALLA et al., 2006). Some flavonoids are reported to enhance brain capacity and longevity (DRAGO et al., 2006).

\section{Total anthocyanins}

We reported that $\mathrm{MgSO}_{4}$ produced more anthocyanins than $\mathrm{MgCl}_{2}$ for the same dose (Figure 1C), where $\mathrm{MgCl}_{2}$ result was not significantly different from the control (Figure 2C). The anthocyanins content for all doses of $\mathrm{MgSO}_{4}$ (average $0.29 \mathrm{mg}$ of cyanidin-3glucoside $\mathrm{g}^{-1}$ ) was higher than for all doses of $\mathrm{MgCl}_{2}$ (average $0.11 \mathrm{mg}$ of cyanidin-3-glucoside $\mathrm{g}^{-1}$ ). With $100 \mathrm{ppm}$ of $\mathrm{MgSO}_{4}$ the anthocyanins content was highest with $0.31 \mathrm{mg}$ of cyanidin-3-glucoside $\mathrm{g}^{-1}$; that is, $10 \%$ higher than the treatment that follows
$\left(\mathrm{MgSO}_{4}\right.$ with $\left.200 \mathrm{ppm}\right)$ and $64 \%$ better than the treatments with $\mathrm{MgCl}_{2}$. Anthocyanins are classified as phenolic compounds that belong to the group of flavonoids. They are pigments that confer colour to flowers, fruits and seeds (MARTÍN et al., 2017), such bean seed coat offering health benefits.

Anthocyanins are chemopreventive agents which its consumption through vegetables with high contents of phenolic compounds, reduced the propensity to diseases cardiac, cerebrovascular, lower mortality rates for cancer, diabetes, obesity and osteoporosis (SHEN et al., 2017). The anthocyanins in beans are located mainly in seed coats (MOJICA et al., 2015). Derived from this study, we recommend biofortifying beans with $\mathrm{MgSO}_{4}$ dose of $100 \mathrm{ppm}$ to increase anthocyanins content in snap beans.

\section{Antioxidant capacity}

The antioxidant capacity values in this study were similar between $\mathrm{MgCl}_{2}$ and $\mathrm{MgSO}_{4}$ 
treatments (Figure 1D). Among the doses significant differences were reported. The dose of $100 \mathrm{ppm}$ of $\mathrm{MgSO}_{4}$ showed the highest level of antioxidant capacity, exceeding the treatment that follows by $25 \%$ scavenging activity $\left(200 \mathrm{ppm}\right.$ of $\left.\mathrm{MgCl}_{2}\right)$. The dose of $100 \mathrm{ppm}$ of $\mathrm{MgSO}_{4}$ had $78 \%$ scavenging activity (Figure $2 \mathrm{D}$ ).

This dose was better than the 200 ppm dose where $55 \%$ scavenging activity was obtained. Similar percentages were reported by SANCHEZ et al. (2017) and HERRERA-HERNÁNDEZ et al. (2018) who found values ranged from $45-80 \%$ scavenging activity in biofortification studies in beans.

Due to the high concentration of total flavonoids, total anthocyanins and antioxidant capacity we found in this experiment, we recommend the 'common bean' var. Strike to be biofortified with $\mathrm{MgSO}_{4}$ reducing malnutrition.

Nowadays, there is considerable interest in consuming antioxidants, in particular in those that prevent the harmful effects of free radicals in the human body. There is also a preference for antioxidants obtained from natural sources. Therefore, it is useful to study the secondary metabolites with anti freeradicals activity in the edible parts of the plants.

The common bean contains a large quantity of polyphenols which are BC with antioxidant properties that neutralize free radicals and chelate transition metals, so counteracting the oxidative processes (AKOND et al., 2011). According to AKILLIOGLU \& KARAKAYA (2010), the antioxidant activity of the 'common bean' is increased or maintained (SANCHO et al., 2015) after digestion.

Our study focuses on the effects of $\mathrm{Mg}$ on the antioxidant capacity and on BC, because the element in crops serves as a regulator of cationic-anionic equilibrium in cells and in turgor regulation in osmotically active ion regulatory cells (MARSCHNER, 2012; GERENDÁS \& FÜHRS, 2013). Also it is involved in protein synthesis as well as being associated with the chlorophyll pigments (GUO et al., 2016), acting as a cofactor of enzymes involved in photosynthetic carbon fixation and metabolism (MAATHUIS, 2009; HERMANS et al., 2013) and subsequently crop yield (SHARMA et al., 2012).

Besides, it is essential for the tertiary conformation of nucleic acids (SREEDHARA \& COWAN, 2002), proteins (MARSCHNER, 2012), cell membranes and cell walls, as well as in maintaining enzyme activities such as $\mathrm{H}^{+}$-ATPase, kinases and polymerases (HERMANS et al., 2013). In addition, $\mathrm{Mg}$ is an element present as a divalent

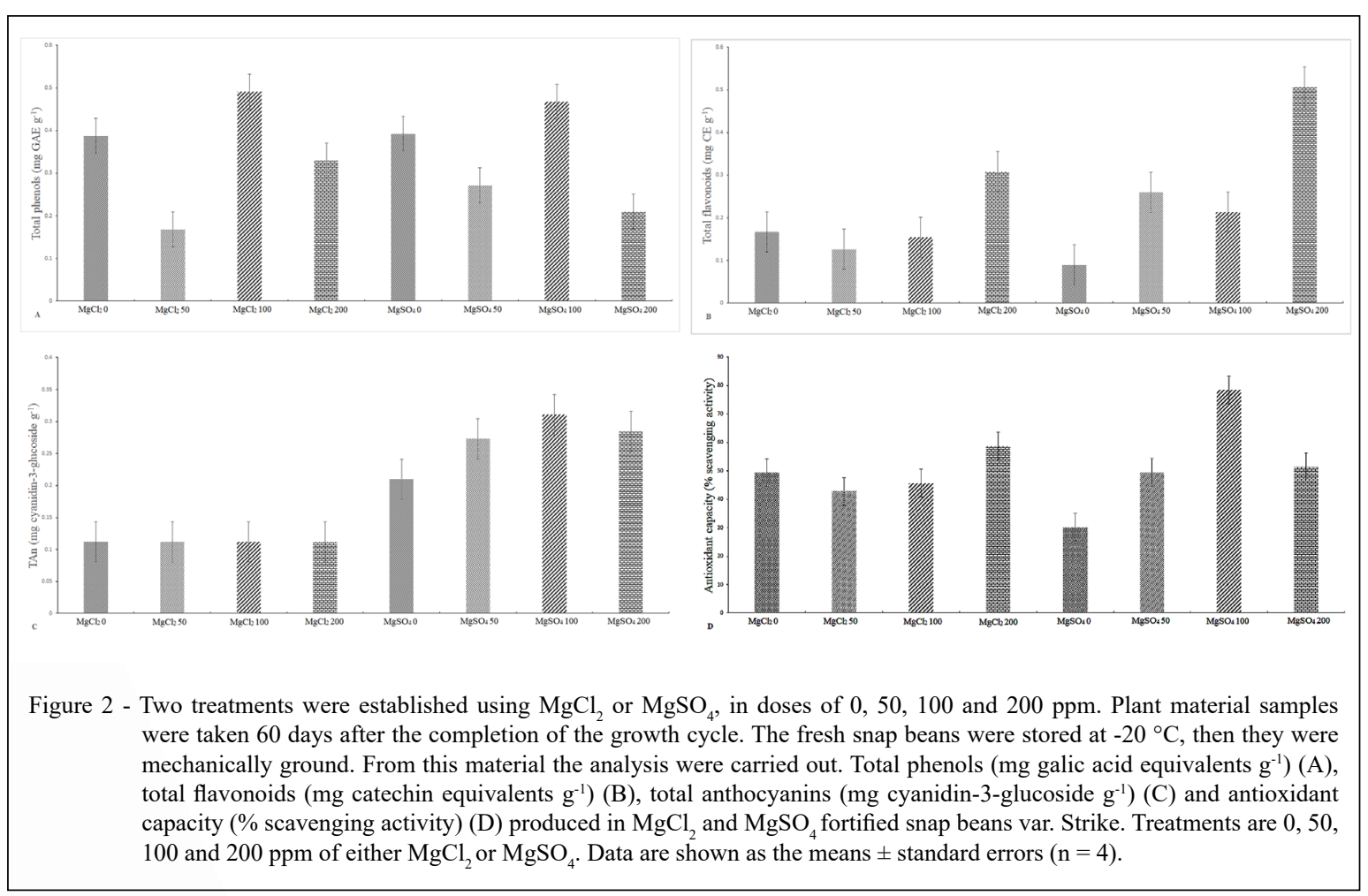

Ciência Rural, v.51, n.6, 2021. 
cation in the soil solution. As it binds less strongly with soil particles than some other cations, it is more prone to leaching. Furthermore, $\mathrm{Mg}$ is usually supplied to crops such as the sulphate since it provides readily available $\mathrm{Mg}^{2+}$ (STEINER et al., 2018). Since $\mathrm{Mg}$ is mobile in the phloem, it is easily translocated to fruits, seeds and tubers (MAATHUIS et al., 2011).

\section{CONCLUSION}

This study provided scientific novelty, since it was demonstrated that the nutritional quality of snap beans could be improved by biofortification with magnesium chloride and sulfate. Results provide important information on the dose of the two magnesium salts applied by edaphic route to increase bioactive compounds and antioxidant capacity in snap beans. The key result in this study is that magnesium sulfate raised total anthocyanins more than magnesium chloride in the edible parts of the plant -snap beans-. Based on the high concentration of total flavonoids, total anthocyanins and antioxidant capacity in the Magnesium biofortified plants, it is feasible to recommend the application of a biofortification programme on 'common beans' with magnesium sulfate at a dose of $100 \mathrm{ppm}$ to reduce malnutrition.

\section{ACKNOWLEDGEMENTS}

This study was funded by the Faculty of Agrotechnological Sciences of the Universidad Autonoma de Chihuahua and Centro de Investigación en Alimentación y Desarrollo AC, Coordinacion Delicias.

\section{DECLARATION OF CONFLICT OF INTERESTS}

The authors declare no conflict of interest. The funding sponsors had no role in the design of the study; in the collection, analyses, or interpretation of data; in the writing of the manuscript, and in the decision to publish the results.

\section{AUTHORS' CONTRIBUTIONS}

All authors contributed equally for the conception and writing of the manuscript. All authors critically revised the manuscript and approved of the final version.

\section{REFERENCES}

ABBOTT, L. G.; RUDE, R. K. Clinical manifestations of magnesium deficiency. Mineral and Electrolyte Metabolism, v.19, n.4-5, p.314-322, 1993. Available from: <https://europepmc. org/article/med/8264519>. Accessed: May, 07, 2020.
AKILLIOGLU, H. G.; KARAKAYA, S. Changes in total phenols, total flavonoids, and antioxidant activities of common beans and pinto beans after soaking, cooking, and in vitro digestion process. Food Science and Biotechnology, v.19, n.3, p.633-639, 2010. Available from: <https://link.springer.com/article/10.1007/ s10068-010-0089-8>. Accessed: May, 07, 2020. doi: 10.1007/ s10068-010-0089-8.

AKOND, A. S. M. G. M. et al. Anthocyanin, total polyphenols and antioxidant activity of common bean. American Journal of Food Technology, v.6, n.5, p.385-394, 2011. Available from: <http:// docsdrive.com/pdfs/academicjournals/ajft/2011/385-394.pdf $>$. Accessed: May, 07, 2020. doi: 10.3923/ajft.2011.385.394.

ALHOSAINI, M.; LEEHEY, D. J. Magnesium and dialysis: the neglected cation. American Journal of Kidney Diseases, v.66, n.3, p.523-531, 2015. Available from: $<$ https://www.sciencedirect. com/science/article/abs/pii/S027263861500517X>. Accessed: May, 07, 2020. doi: 10.1053/j.ajkd.2015.01.029.

BOUIS, H. E.; SALTZMAN, A. Improving nutrition through biofortification: a review of evidence from HarvestPlus, 2003 through 2016. Global Food Security, v.12, p.49-58, 2017. Available from: <https://www.sciencedirect.com/science/article/ pii/S2211912417300068>. Accessed: May, 07, 2020. doi: 10.1016/j.gfs.2017.01.009.

BOUIS, H. E.; WELCH, R. M. Biofortification -a sustainable agricultural strategy for reducing micronutrient malnutrition in the global south. Crop Science, v.50, n.1, p.S-20, 2010. Available from: $\quad<$ https://acsess.onlinelibrary.wiley.com/doi/full/10.2135/ cropsci2009.09.0531>. Accessed: May, 07, 2020. doi: 10.2135/ cropsci2009.09.0531.

DAVID, A. V. A. et al. Overviews of biological importance of quercetin: A bioactive flavonoid. Pharmacogn Reviews, v.10, n.20, p.84-89, 2016. Available from: <https://www.ncbi.nlm.nih. gov/pmc/articles/PMC5214562/>. Accessed: May, 07, 2020. doi: 10.4103/0973-7847.194044.

DE BAAIJ, J. H. et al. Magnesium in man: implications for health and disease. Physiological Reviews, v.95, n.1, p.1-46, 2015. Available from: < https://journals.physiology.org/doi/full/10.1152/ physrev.00012.2014>. Accessed: May, 07, 2020. doi: 10.1152/ physrev.00012.2014

DÍAZ-BATALLA, L. et al. Chemical components with health implications in wild and cultivated Mexican common bean seeds (Phaseolus vulgaris L.). Journal of Agriculural and Food Chemistry, v.54, n.6, p.2045-2052, 2006. Available from: $<$ https:// pubs.acs.org/doi/abs/10.1021/jf0517061>. Accessed: May, 07, 2020. doi: 10.1021/jf0517061.

DRAGO, S. M. E. et al. Bioactive components of functional foods from vegetable origin. Revista Mexicana de Ciencias Farmaceuticas, v.37, n.4, p.58-68, 2006. Available from: $<$ https://www.redalyc.org/pdf/579/57937408.pdf $>$. Accessed: May, 07, 2020.

FAO. Phaseolus bean: Post-harvest operations. Available from: $<$ http://www.fao.org/3/a-av015e.pdf $>$. 2018. Accessed: May, $07,2020$.

GERENDÁS, J.; FÜHRS H. The significance of magnesium for crop quality. Plant and Soil, v.368, n.1-2, p.101-128, 2013. Available from: <https://link.springer.com/article/10.1007/ 
s11104-012-1555-2>. Accessed: May, 07, 2020. doi: 10.1007/ s11104-012-1555-2.

GUO, W. et al. Magnesium deficiency in plants: an urgent problem. The Crop Journal, v.4, n.2, p.83-91, 2016. Available from: $\quad<$ https://www.sciencedirect.com/science/article/pii/ S221451411500121X>. Accessed: May, 07, 2020. doi: 10.1016/j. cj.2015.11.003

HANAFY-AHMED, A. H. et al. Effect of some simulative compounds on growth, yield and chemical composition of snap bean plants grown under calcareous soil conditions. Journal of American Science, v.6, n.10, p.552-569, 2010. Available from: $<$ www.americanscience.org > . Accessed: May, 07, 2020.

HEIMLER, D. et al. Rapid test to access the antioxidant activity of Phaseolus vulgaris L. dry beans. Journal of Agricultural and Food Chemistry, v.53, n.8, p.3053-3056, 2005. Available from: $<$ https://pubs.acs.org/doi/abs/10.1021/jf049001r > . Accessed: May, 07, 2020. doi: 10.1021/jf049001r.

HERMANS, C. et al. An update on magnesium homeostasis mechanisms in plants. Metallomics, v.5, n.9, p.1170-1183, 2013. Available from: <https://pubs.rsc.org/en/content/ articlelanding/2013/mt/c3mt20223b/unauth\#!divAbstract $>$. Accessed: May, 07, 2020. doi: 10.1039/c3mt20223b.

HERRERA-HERNÁNDEZ， I. M. et al. Characterization of bioactive compounds, mineral content and antioxidant capacity in bean varieties grown in semi-arid conditions in Zacatecas, Mexico. Foods, v.7, n.12, p.199, 2018. Available from: <https://www. mdpi.com/2304-8158/7/12/199>. Accessed: May, 07, 2020. doi: $10.3390 /$ foods 7120199 .

HÖRTENSTEINER, S.; KRÄUTLER, B. Chlorophyll breakdown in higher plants. Biochimica et Biophysica Acta (BBA) - Bioenergetics, v.1807, n.8, p.977-988, 2011. Available from: $\quad<$ https://www.sciencedirect.com/science/article/pii/ S0005272810007942>. Accessed: May, 07, 2020. doi: 10.1016/j. bbabio.2010.12.007.

HSU, C. L. et al. Chemical composition, physical properties, and antioxidant activities of yam flours as affected by different drying methods. Food Chemistry, v.83, n.1, p.85-92, 2003. Available from: $\quad<$ https://www.sciencedirect.com/science/article/abs/pii/ S0308814603000530>. Accessed: May, 07, 2020. doi: 10.1016/ S0308-8146(03)00053-0.

MAATHUIS, F. J. Physiological functions of mineral macronutrients. Current Opinion in Plant Biology, v.12, n.3, p.250-258, 2009. Available from: <https://www.sciencedirect. com/science/article/pii/S1369526609000284>. Accessed: May, 07, 2020. doi: 10.1016/j.bbabio.2010.12.007.

MAATHUIS, F. J. et al. Uptake, distribution, and physiological functions of potassium, calcium, and magnesium. In: HAWKESFORD, M.J.; BARRACLOUGH, P. The molecular and physiological basis of nutrient use efficiency in crops. John Wiley \& Sons, UK, 2011. p.265-293.

MÁRQUEZ-QUIROZ, C. et al. Biofortification of cowpea beans with iron: iron's influence on mineral content and yield. Journal of Soil Science and Plant Nutrition, v.15, n.4, p.839-847, 2015 Available from: <https://scielo.conicyt.cl/scielo.php?pid=S0718$95162015000400003 \& \mathrm{script}=\mathrm{sci}$ arttext\&tlng $=\mathrm{p}>$. Accessed: May, 07, 2020. doi: 10.4067/S0718-95162015005000058.
MARSCHNER, H. Mineral nutrition of higher plants. Academic Press, Elsevier, London, UK, 2012. 889p.

MARTÍN, J. et al. Anthocyanin pigments: Importance, sample preparation and extraction. In: SOTO-HERNÁNDEZ, M.; PALMA-TENANGO, M.; GARCÍA-MATEOS, R. Phenolic compounds-Natural sources, importance and applications. InTech. Rijeka, Croatia, 2017. p.117-152. Available from: $<$ https:// www.intechopen.com/books/phenolic-compounds-naturalsources-importance-and-applications/anthocyanin-pigmentsimportance-sample-preparation-and-extraction>. Accessed: May, 07, 2020. doi: 10.5772/66892.

MOJICA, L. et al. Bean cultivars (Phaseolus vulgaris L.) have similar high antioxidant capacity, in vitro inhibition of $\alpha$-amylase and $\alpha$-glucosidase while diverse phenolic composition and concentration. Food Research International, v.69, p.38-48, 2015. Available from: <https://www.sciencedirect.com/science/article/ abs/pii/S0963996914007777>. Accessed: May, 07, 2020. doi: 10.1016/j.foodres.2014.12.007.

RONDON, M. A. et al. Biological nitrogen fixation by common beans (Phaseolus vulgaris L.) increases with bio-char additions. Biology and Fertility of Soils, v.43, n.6, p.699-708, 2007. Available from: <https://link.springer.com/article/10.1007/ s00374-006-0152-z>. Accessed: May, 07, 2020. doi: 10.1007/ s00374-006-0152-z.

ROSANOFF, A. Changing crop magnesium concentrations: impact on human health. Plant and Soil, v.368, p.139-153, 2013. Available from: $<$ https://link.springer.com/article/10.1007/s11104012-1471-5>. Accessed: Oct. 25, 2020. doi: 10.1007/s11104-0121471-5.

SANCHO, R. A. S. et al. Effect of in vitro digestion on bioactive compounds and antioxidant activity of common bean seed coats. Food Research International, v.76, p.74-78, 2015. Available from: $\quad<$ https://www.sciencedirect.com/science/article/abs/pii/ S096399691400756X>. Accessed: May, 07, 2020. doi: 10.1016/j. foodres.2014.11.042.

SHARMA, P. et al. Reactive oxygen species, oxidative damage, and antioxidative defense mechanism in plants under stressful conditions. Journal of Botany, Art. ID 217037, p.1-26, 2012. Available from: <https://www.hindawi.com/ journals/jb/2012/217037/>. Accessed: May, 07, 2020. doi: $10.1155 / 2012 / 217037$.

SHEN, T. et al. Protective effects of dietary polyphenols in human diseases and mechanisms of action. In: ALGUBORY, K.; LAHER, I. Nutritional antioxidant therapies: Treatments and perspectives. Springer, Cham. Switzerland, 2017. p. 307-345, Available from: <https://link.springer.com/ chapter/10.1007/978-3-319-67625-8_13>. Accessed: May, 07, 2020. doi: 10.1007/978-3-319-67625-8 13 .

SIDA-ARREOLA, J. P. et al. Iron biofortification and its impact on antioxidant system, yield and biomass in common bean. Plant Soil and Environment, v.61, n.12, p.573-576, 2015. Available from: <https://www.agriculturejournals.cz/ publicFiles/643 2015-PSE.pdf >. Accessed: May, 07, 2020. doi: $10.17221 / 643 / 2015$-PSE

SANCHEZ, E. et al. Can biofortification of zinc improve the antioxidant capacity and nutritional quality of beans? Emirates Journal of Food and Agriculture, v.29, n.3, p.237-242, 2017. 
Available from: <http://www.ejfa.me/index.php/journal/article/ view/602>. Accessed: May, 07, 2020. doi: 10.9755/ejfa.2016-04-367.

SINGLETON, V. L.; ROSSI, J. A. Colorimetry of total phenolics with phosphomolybdic phosphotungstic acid reagents. American Journal of Enology and Viticulture, v.16, n.3, p.144-158, 1965. Available from: <https://www.ajevonline.org/content/16/3/144. short>. Accessed: May, 07, 2020.

SINGLETON, V. L. et al. Caftaric acid disappearance and conversion to products of enzymatic oxidation in grape must and wine. American Journal of Enology and Viticulture, v.36, n.1, p.50-56, 1985. Available from: <https://www.ajevonline.org/ content/36/1/50.short>. Accessed: May, 07, 2020.

SREEDHARA, A.; COWAN, J. A. Structural and catalytic roles for divalent magnesium in nucleic acid biochemistry. Biometals, v.15, n.3, p.211-223, 2002. Available from: <https://link.springer com/article/10.1023/A:1016070614042>. Accessed: May, 07, 2020. doi: 10.1023/A:1016070614042.

STEINER, A. A. A universal method for preparing nutrient solutions of a certain desired composition. Plant and Soil, v.15, n.2, p.134-154, 1961. Available from: <https://link.springer.com/ article/10.1007/BF01347224>. Accessed: May, 07, 2020. doi: $10.1007 / \mathrm{BF} 01347224$.

STEINER, C. et al. The nitrogen contained in carbonized poultry litter is not plant available. Open Agriculture, v.3, n.1, p.284-
290, 2018. Available from: <https://www.degruyter.com/view/ journals/opag/3/1/article-p284.xml>. Accessed: May, 07, 2020. doi: 10.1515/opag-2018-0030.

SUÁREZ-MARTÍNEZ, S. E. et al. Bean seeds: leading nutraceutical source for human health. CyTA-Journal of Food, v.14, n.1, p.131137, 2016. Available from: $<$ https://www.tandfonline.com/doi/full/ 10.1080/19476337.2015.1063548>. Accessed: May, 07, 2020. doi: $10.1080 / 19476337.2015 .1063548$.

WACKER, W. E.; PARISI, A. F. Magnesium metabolism. New England Journal of Medicine, v.278, n.14, p.658-663, 1968. Available from: <https://www.nejm.org/doi/pdf/10.1056/ NEJM196804042781406>. Accessed: May, 07, 2020. doi: 10.1056/NEJM196804042781406.

WHITE, P. J.; BROADLEY, M. R. Biofortification of crops with seven mineral elements often lacking in human diets-iron, zinc, copper, calcium, magnesium, selenium and iodine. New Phytologist, v.182, n.1, p.49-84, 2009. Available from: <https://nph.onlinelibrary. wiley.com/doi/full/10.1111/j.1469-8137.2008.02738.x>. Accessed: May, 07, 2020. doi: 10.1111/j.1469-8137.2008.02738.x.

ZHISHEN, J. et al. The determination of flavonoid contents in mulberry and their scavenging effects on superoxide radicals. Food Chemistry, v.64, n.4, p.555-559, 1999. Available from: <https://www.sciencedirect.com/science/article/abs/pii/ S0308814698001022>. Accessed: May, 07, 2020. doi: 10.1016/ S0308-8146(98)00102-2. 